\title{
Microwave synthesis of electrode materials for lithium batteries
}

\author{
M HARISH BHAT, B P CHAKRAVARTHY, P A RAMAKRISHNAN, A LEVASSEUR ${ }^{\dagger}$ \\ and K J RAO*
}

Solid State and Structural Chemistry Unit, Indian Institute of Science, Bangalore 560 012, India

${ }^{\dagger}$ ENSCPB, Avenue Pey Berland, BP 108, 334 02, Talence Cedex, Bordeaux, France

MS received 7 November 2000

\begin{abstract}
A novel microwave method is described for the preparation of electrode materials required for lithium batteries. The method is simple, fast and carried out in most cases with the same starting material as in conventional methods. Good crystallinity has been noted and lower temperatures of reaction has been inferred in cases where low temperature products have been identified.
\end{abstract}

Keywords. Novel microwave method; electrode materials; lithium batteries.

\section{Introduction}

There has been an increasing interest in the development of Li batteries for the last two decades, owing primarily to the higher voltages and energy densities realizable in them. The problems of safety associated with the use of $\mathrm{Li}$ metal due to its chemical reactivity with the ambient and the problems of dendritic regrowth of $\mathrm{Li}$ on the anode upon cycling, which leads to short-circuiting of the cell, have been the major disadvantages of Li batteries. This is sought to be overcome by the introduction of a more advanced and inherently safe 'rocking chair' configuration of lithium batteries (so called because the Li ions rock back and forth between the two electrodes during charge/discharge cycles). Rocking chair batteries use insertion compounds as electrode materials for both the anode and the cathode (Murphy et al 1978; Murphy and Carides 1979; Lazzari and Scrosati 1980; Mizushima et al 1980). The output voltage of such cells is determined by the difference between the electrochemical potential of $\mathrm{Li}^{+}$ions in the two electrodic insertion compounds. It is implied that the cathode and anode should be compounds which can be intercalated with $\mathrm{Li}^{+}$ions at high and low voltages respectively.

Intensive research on electrode materials has shown that for the negative electrode (anode), Li metal can be replaced effectively either by a Li-Al alloy (Peled et al 1983 ) or by intercalation materials based on carbon (Kanno et al 1989; Mohri et al 1989; Fong et al 1990). The loss in the voltage due to the $\mathrm{Li}^{+}$potential in intercalated carbon compared to Li metal itself is compensated by the use of cathode materials with higher oxidation potentials. Some of the materials which meet this require-

\footnotetext{
*Author for correspondence
}

ment are $\mathrm{LiMn}_{2} \mathrm{O}_{4}$ (Tarascon and Guyomard 1991, 1993; Guyomard and Tarascon 1992), $\mathrm{LiCoO}_{2}$ (Thomas et al 1985; Gummow et al 1992) and $\mathrm{LiNiO}_{2}$ (Dahn et al 1990, 1991; Ozawa 1994). In batteries employing glassy electrolytes, compounds like $\mathrm{TiS}_{2}, \mathrm{Cu}_{4} \mathrm{O}\left(\mathrm{PO}_{4}\right)_{2}, \mathrm{CuBi}_{2} \mathrm{O}_{4}$, $\mathrm{Bi}_{4} \mathrm{~B}_{2} \mathrm{O}_{9}$ have been used as cathodes (Jones and Akridge 1995). It has been found that in all these cases, the performance of the electrodes is significantly influenced by the method of their preparation. For example, samples synthesized at low temperatures show better cyclability but lower capacity than those prepared at higher temperatures. It is, therefore, necessary to develop methods of synthesis, which give rise to materials of better electrode characteristics and are also cheap and reproducible.

Use of microwaves for the synthesis of inorganic compounds has gained great importance in recent years (Mingos and Baghurst 1991; Rao and Ramesh 1995; Rao et al 1999). The method offers several advantages over the conventional routes, the most important of them being the very short reaction times and energy economy. Several microwave reactions are now known to occur at lower temperatures than in conventional methods. The rapidity of the reactions offers excellent condition for retention of metastable phases. This novel method has been found to result in better reaction yields and better structural uniformity of products (Rao et al 1999a) than conventional ceramic methods. Further, the microwave method is also very clean and non-polluting. The rapidity of the reactions offers excellent possibilities for stabilizing metastable phases. This novel method has been found to result in better reaction yields and better structural uniformity of products. In order to use the microwave route, it is desirable that at least one of the reactants should be a microwave susceptor. However, this limitation can be overcome by the use of a secondary susceptor, which is chemically inert with respect to the reactants of interest. A micro- 
wave susceptor like graphite, which is generally nonreactive, is a superb secondary heater (Vaidhyanathan et al 1997). Researches at our laboratory and elsewhere have demonstrated the use of microwaves in the synthesis of a wide variety of oxides (Vaidhyanathan et al 1997; Baghurst and Mingos 1988; Baghurst et al 1988; Kladnig and Horn 1990), chalcogenides (Whittaker and Mingos 1992; Landry and Barron 1993; Kniep 1993; Vaidhyanathan et al 1995), carbides (Clark et al 1991; Ahmad et al 1991; Ramesh et al 1994), nitrides (Kiggans et al 1991; Ramesh and Rao 1995; Vaidhyanathan and Rao 1997a), silicides (Vaidhyanathan and Rao 1997b), borides (Mingos and Baghurst 1992) and glasses (Vaidhyanathan et al 1994, 1998). Therefore, we consider it important to develop a microwave route to synthesize electrode materials and examine their electrode characteristics. Materials like $\mathrm{LiMn}_{2} \mathrm{O}_{4}, \mathrm{LiCoO}_{2}, \mathrm{CuBi}_{2} \mathrm{O}_{4}$ and $\mathrm{Bi}_{4} \mathrm{~B}_{2} \mathrm{O}_{9}$ have potential application in Li batteries. We report here a microwave method for the synthesis of these materials.

\section{Experimental}

Oxides or carbonates and iodides were used as reactants for the preparation of the complex oxides. Amorphous carbon was used as a secondary heater in some cases. Stoichiometric amounts of the required high purity reactants (total weight $=5-10 \mathrm{~g}$ ) were ground well in each case and exposed to microwave irradiation for about 5-10 min in silica crucibles kept inside a domestic microwave oven (Batliboy-Eddy, 2.45 GHz, $980 \mathrm{~W}$ ) operating at the highest power level. In some cases, the reaction was interrupted at the end of every $2 \mathrm{~min}$ and the partially reacted mixtures were ground well again to ensure homogeneity. Product formation was confirmed by powder X-ray diffraction (Philips, Model PW1050/70, $\mathrm{Cu}-\mathrm{K}_{\alpha}$ radiation). The lattice parameters were calculated using least squares fitting of XRD reflections.

Preliminary electrochemical characterization was carried out for $\mathrm{LiMn}_{2} \mathrm{O}_{4}$ by configuring appropriate cell assembly. Electrodes were made by mixing the active material with PVDF (binder) and acetylene black in the ratio $80: 10: 10$ by weight and pressing them as pellets. The pellets were heated to $175^{\circ} \mathrm{C}$ and were pressed once again at that temperature. A liquid electrolyte $\left(\mathrm{LiClO}_{4}+\mathrm{EC}\right.$ + DEC) was used and was separated using polypropylene.

\section{Results and discussion}

\section{$3.1 \mathrm{LiMn}_{2} \mathrm{O}_{4}$}

The microwave preparation of lithium manganate was first attempted with $\mathrm{Li}_{2} \mathrm{CO}_{3}$ and $\mathrm{MnO}_{2}$ as reactants. But the expected cubic spinel phase of $\mathrm{LiMn}_{2} \mathrm{O}_{4}$ was not formed. Instead a mixed phase of defect spinels of $\mathrm{Li}_{2} \mathrm{O}-$ $y \mathrm{MnO}_{2}$ was found to form. This in itself is quite interesting because the defect spinel is reported to be stable only below $400^{\circ} \mathrm{C}$ and upon heating above $400^{\circ} \mathrm{C}$, it transforms to the cubic spinel. Therefore, the metastable phase seems to get stabilized easily in microwave preparation. This may be due to low microwave susceptibility of $\mathrm{MnO}_{2}$, which does not enable the system to attain high $\left(>400^{\circ} \mathrm{C}\right)$ temperature. The temperatures could not be measured in these experiments.

An alternate reaction scheme was used for the microwave preparation of the cubic spinel phase. An intimate mixture of $\mathrm{LiI}$ and $\mathrm{MnO}_{2}$ was irradiated by microwaves. It was found that cubic spinel was formed directly in a single heating step of $6 \mathrm{~min}$. The other product was iodine, which was in the gaseous phase and it provided an antioxidative shroud around the reaction mixture

$$
\mathrm{LiI}+2 \mathrm{MnO}_{2} \rightarrow \mathrm{LiMn}_{2} \mathrm{O}_{4}+\frac{1}{2} \mathrm{I}_{2}
$$

Lattice parameter, $a$, of the cubic spinel phase was calculated by least squares fitting and found to be $8 \cdot 244 \AA$. This value agrees very well with that reported in the literature ( $a=8 \cdot 2476 \AA$ ) [JCPDS, File No. 35-782]. The XRD pattern is shown in figure 1 . The crystallinity of the product appears to be poor. The low microwave susceptibility of $\mathrm{MnO}_{2}$ appears to limit the temperature attained by the

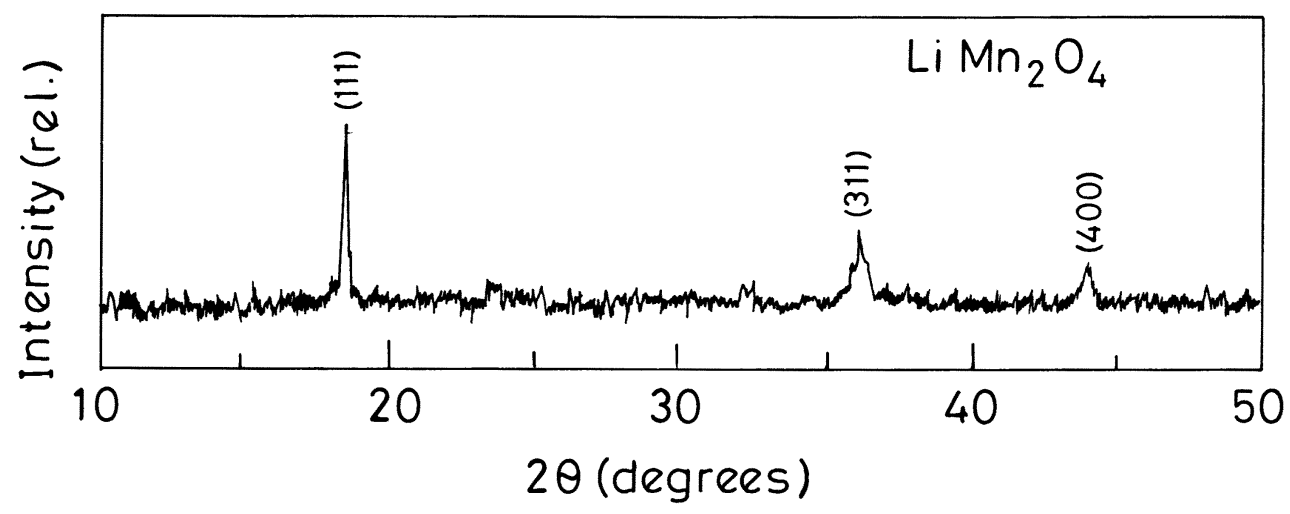

Figure 1. Powder X-ray diffraction pattern of microwave prepared cubic spinel, $\mathrm{LiMn}_{2} \mathrm{O}_{4}$. 
reactants. Also the reaction does not appear to be highly exothermic. As a consequence the temperature attained appears insufficient for achieving good crystallinity.

Alternately, $\mathrm{LiMn}_{2} \mathrm{O}_{4}$ was prepared by using stoichiometric quantities of $\mathrm{Li}_{2} \mathrm{CO}_{3}$ and $\mathrm{MnO}_{2}$, but by embedding a pellet of the mixture in amorphous carbon (used as a secondary heater) before irradiating with microwaves. The reaction was found to be completed in about $7 \mathrm{~min}$ of continuous irradiation and a cubic spinel of $\mathrm{LiMn}_{2} \mathrm{O}_{4}$ was found to form:

$$
\begin{aligned}
& \mathrm{Li}_{2} \mathrm{CO}_{3}+2 \mathrm{MnO}_{2} \text { (pellet of mixture in carbon) } \rightarrow \\
& 2 \mathrm{LiMn}_{2} \mathrm{O}_{4}+\mathrm{CO}_{2} .
\end{aligned}
$$

However, the high temperature attained during the synthesis (since amorphous carbon is used as secondary heater) results in the formation of fine powders with somewhat poor crystallinity.

$\mathrm{LiMn}_{2} \mathrm{O}_{4}$ of spinel structure possesses cathode reversibility of intercalated $\mathrm{Li}^{+}$ions above $4 \mathrm{~V}$. Also, $\mathrm{LiMn}_{2} \mathrm{O}_{4}$ is not moisture sensitive and can be handled in ambient atmosphere. In comparison with the layered materials like $\mathrm{LiCoO}_{2}$ and $\mathrm{LiNiO}_{2}, \mathrm{LiMn}_{2} \mathrm{O}_{4}$ is cheaper and environmentally benign. Formation of spinel lithium manganate is very sensitive to preparative conditions. The conventional method of preparation of $\mathrm{LiMn}_{2} \mathrm{O}_{4}$ involved solid state reaction of $\mathrm{Li}_{2} \mathrm{CO}_{3}$ and $\mathrm{Mn}_{2} \mathrm{O}_{3}$ above $1150 \mathrm{~K}$. Alternate synthetic routes based on precursor (Huang and Bruce 1994, 1995) and sol-gel (Barboux et al 1991) methods have also been reported. Microwave method described above is therefore, clearly faster, cleaner and economical than other methods.

A preliminary electrochemical characterization has been performed using two different anodes $\left(\mathrm{Li}_{0 \cdot 3} \mathrm{~V}_{2} \mathrm{O}_{5}\right.$ and graphitic carbon) having the configuration

$$
\begin{aligned}
& \mathrm{Li}_{0 \cdot 3} \mathrm{~V}_{2} \mathrm{O}_{5}\left|\mathrm{LiClO}_{4}+\mathrm{EC}+\mathrm{DEC}\right| \mathrm{LiMn}_{2} \mathrm{O}_{4}, \\
& \text { graphitic C }\left|\mathrm{LiClO}_{4}+\mathrm{EC}+\mathrm{DEC}\right| \mathrm{LiMn}_{2} \mathrm{O}_{4} .
\end{aligned}
$$

Batteries fabricated using $\mathrm{Li}_{0 \cdot 3} \mathrm{~V}_{2} \mathrm{O}_{5}$ and $\mathrm{LiMn}_{2} \mathrm{O}_{4}$ as electrodes showed low voltages as well as low capacities (figure 2a). Note here that the $\mathrm{Li}_{0 \cdot 3} \mathrm{~V}_{2} \mathrm{O}_{5}$ used was also prepared by a microwave method reported elsewhere (Rao et al 1999b). The low voltage of this battery is due to the small difference in the potentials of the electrode materials (w.r.t. Li). The expected voltages being $E \approx 3.4 V$ for $\mathrm{Li}_{0 \cdot 3} \mathrm{~V}_{2} \mathrm{O}_{5} / \mathrm{Li}$ and $E \approx 4.2 V$ for $\mathrm{LiMn}_{2} \mathrm{O}_{4} / \mathrm{Li}$.

Poor intercalatability of $\mathrm{Li}$ into the electrode materials results in low capacity. When graphitic carbon was used as an anode instead of $\mathrm{Li}_{0 \cdot 3} \mathrm{~V}_{2} \mathrm{O}_{5}$ in the above cell, the voltage was about $3.8 \mathrm{~V}$ but the capacity was not very high (figure $2 \mathrm{~b}$ ). Further studies are in progress.

\section{$3.2 \mathrm{LiCoO}_{2}$}

The layered lithium cobaltate is an important cathode material and has been employed in the commercial batteries manufactured by Sony Energytec (Nagaura 1990). This material was prepared from $\mathrm{LiOH}$ and $\mathrm{Co}\left(\mathrm{NO}_{3}\right)_{2} \cdot 6 \mathrm{H}_{2} \mathrm{O}$ by mixing them in distilled water in $4: 1$ molar ratio $(\mathrm{LiOH}$ taken in excess). The solution was microwave irradiated for $10 \mathrm{~min}$ in order to remove the water. Since neither of the reactant is a microwave susceptor, the temperature did not rise further. The product formed at this stage was amorphous. The sample was heated at $973^{\circ} \mathrm{C}$ for $60 \mathrm{~min}$ and X-ray pattern showed the formation of poorly crystalline $\mathrm{LiCoO}_{2}$ (figure 3a). Alternately, $\mathrm{Li}_{2} \mathrm{CO}_{3}$ and $\mathrm{Co}\left(\mathrm{NO}_{3}\right)_{2} \cdot 6 \mathrm{H}_{2} \mathrm{O}$ were ground into a pellet and embedded
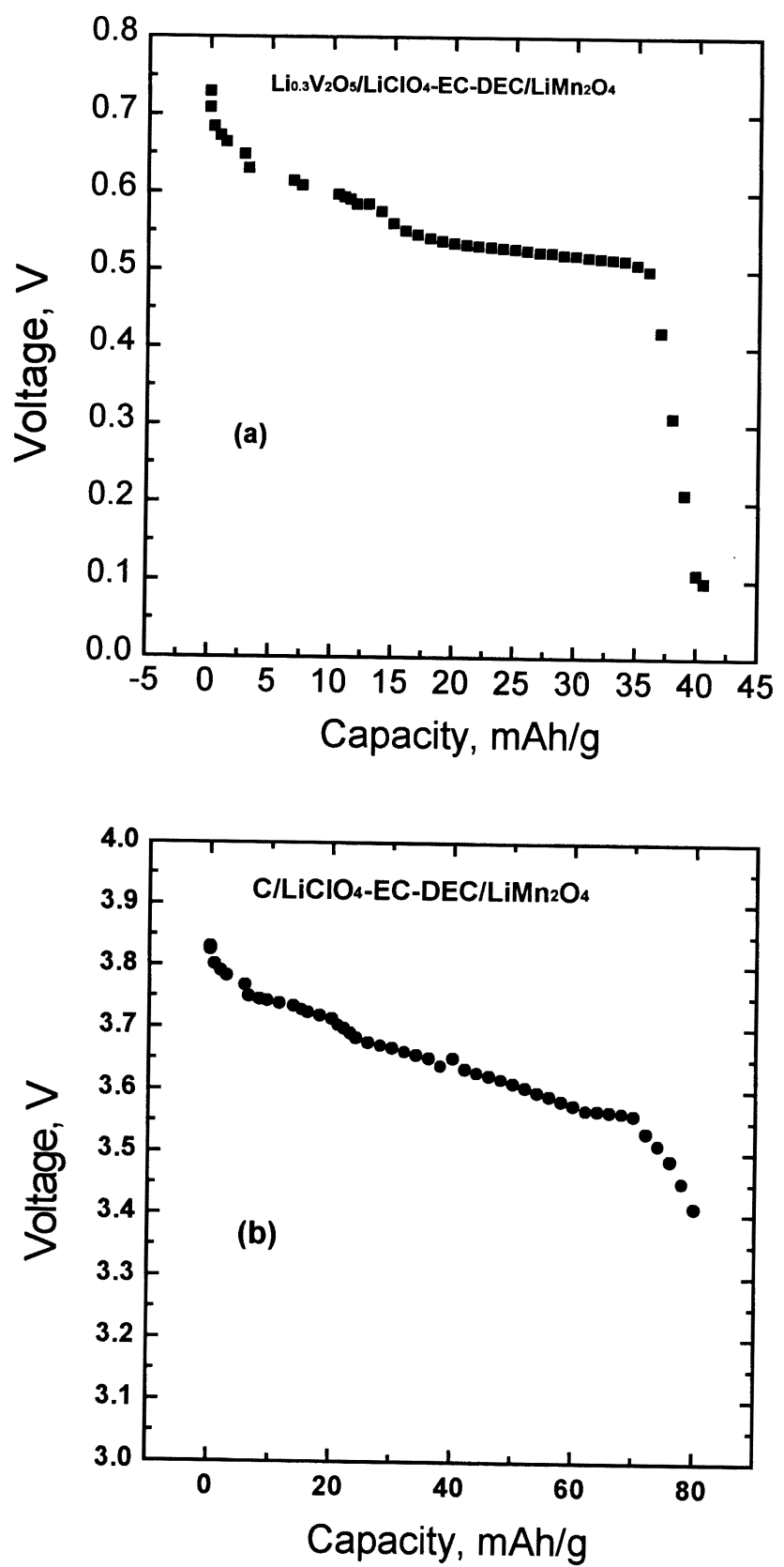

Figure 2. Discharge characteristics of $\mathrm{LiMn}_{2} \mathrm{O}_{4}$ using the anodes (a) $\mathrm{Li}_{0.3} \mathrm{~V}_{2} \mathrm{O}_{5}$ and (b) graphitic carbon, discharged at a constant current of $0 \cdot 2 \mathrm{~mA} / \mathrm{cm}^{2}$. 


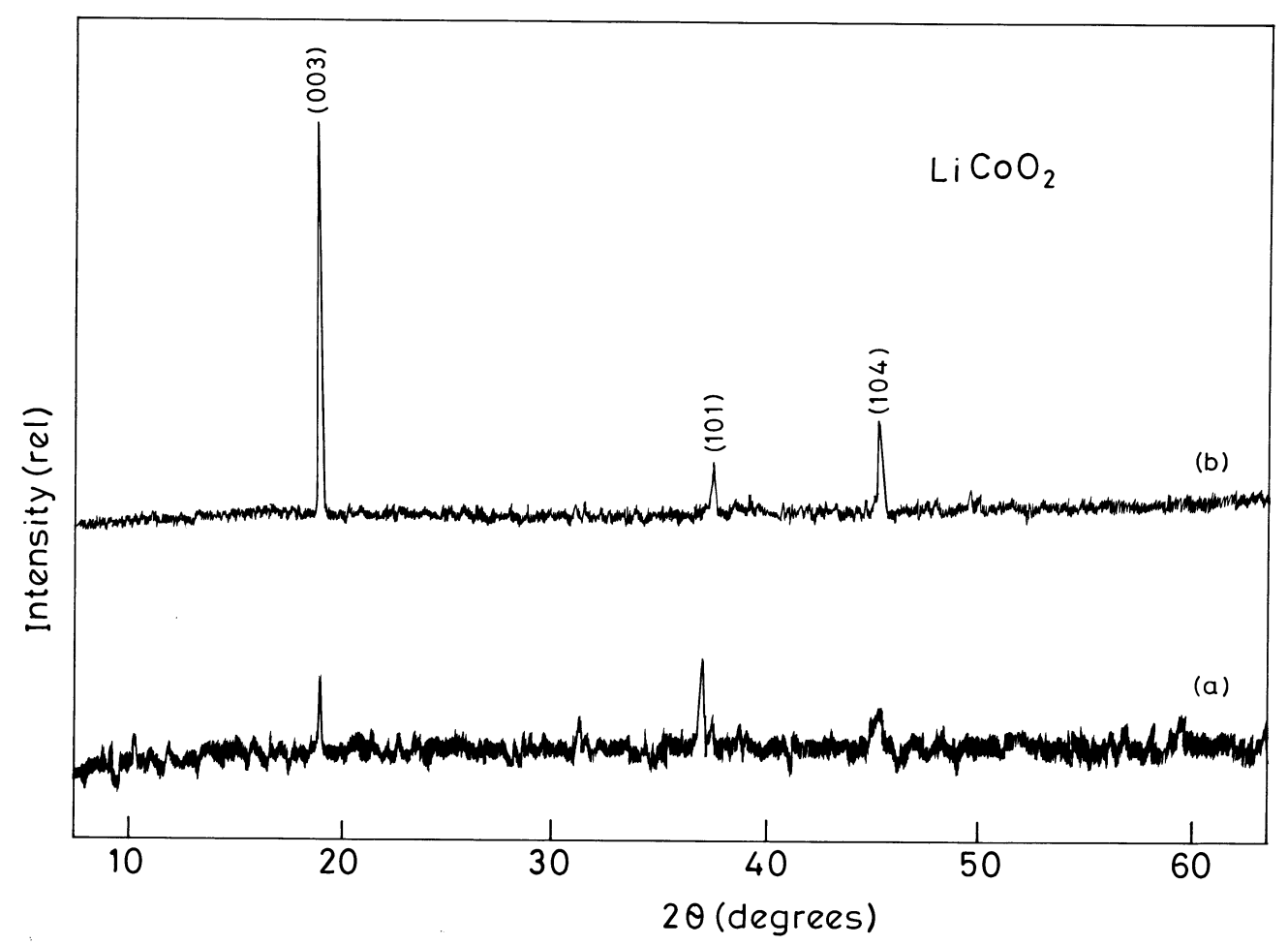

Figure 3. Powder X-ray diffraction pattern of layered $\mathrm{LiCoO}_{2}$ prepared by (a) solution route and (b) solid state route.

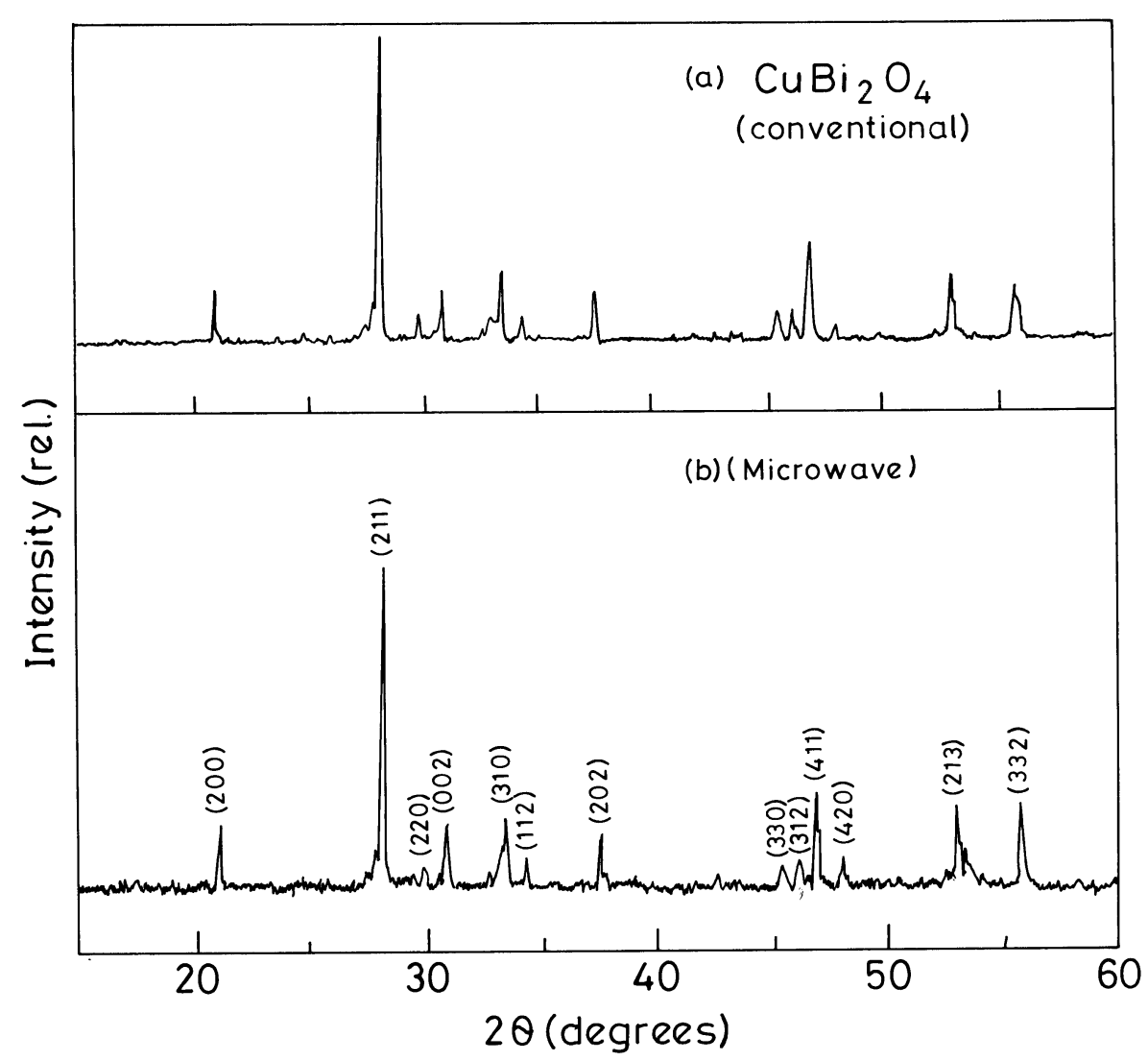

Figure 4. Powder $\mathrm{X}$-ray diffraction pattern of $\mathrm{CuBi}_{2} \mathrm{O}_{4}$ prepared by (a) conventional and (b) microwave methods. 


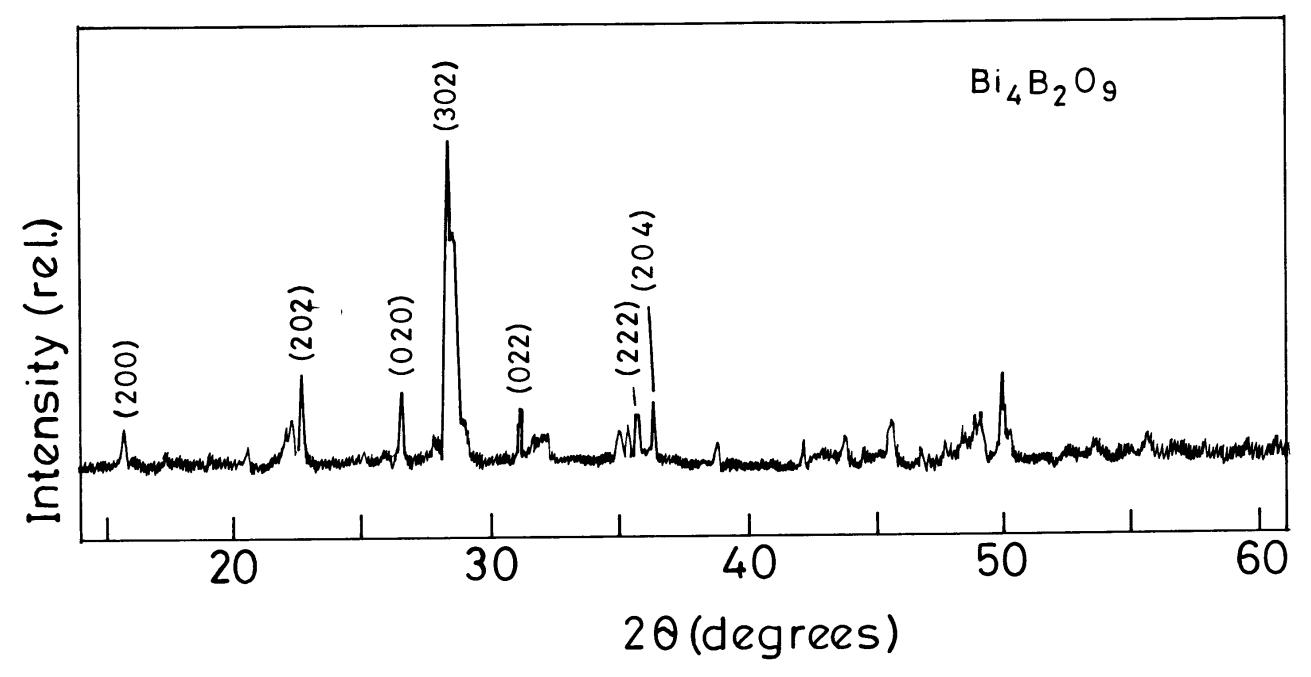

Figure 5. X-ray pattern of $\mathrm{Bi}_{4} \mathrm{~B}_{2} \mathrm{O}_{9}$ prepared by microwave route.

in amorphous carbon, which gave $\mathrm{LiCoO}_{2}$ possessing very good crystallinity (figure $3 \mathrm{~b}$ ) within 5 min of irradiation in microwaves.

\section{$3.3 \mathrm{CuBi}_{2} \mathrm{O}_{4}$}

Microwave irradiation of a mixture of $\mathrm{CuO}$ and $\mathrm{Bi}_{2} \mathrm{O}_{3}$ for just $5 \mathrm{~min}$ yielded monophasic, tetragonal $\mathrm{CuBi}_{2} \mathrm{O}_{4}$ (figure 4a) with lattice parameters $a=8.504 \AA$ and $c=$ $5 \cdot 811 \AA$. These lattice parameter values are in good agreement with literature reports $(a=8.510 \AA$ and $c=5.814 \AA)$ [JCPDS File no. 26-502]. Alternately, when a mixture of $\mathrm{CuO}$ and $(\mathrm{BiO})_{2} \mathrm{CO}_{3}$ was pelletized and embedded in amorphous carbon, the reaction was complete in under a minute. For purposes of comparison, $\mathrm{CuBi}_{2} \mathrm{O}_{4}$ was also prepared using the conventional procedure (Boivin et al 1973). In this procedure, the initial reactants $(\mathrm{CuO}$ and $\mathrm{Bi}_{2} \mathrm{O}_{3}$ ) are heated at $523 \mathrm{~K}$ for $2 \mathrm{~h}$ following which two additional heat treatments are given at 623 and $723 \mathrm{~K}$ for $6 \mathrm{~h}$ each. At every stage, the powders are ground repeatedly. Final heat treatment is given at $873 \mathrm{~K}$ for $4 \mathrm{~h}$. XRD (figure $4 \mathrm{~b}$ ) of the material obtained by this method gave lattice parameters $a=8.503 \AA$ and $c=5 \cdot 817 \AA$. The superiority of the microwave method, which gives the product in a single step irradiation and avoids the several steps involved in the conventional method, is self-evident. Also, the microwave method yields $\mathrm{CuBi}_{2} \mathrm{O}_{4}$ of better crystallinity as can be seen from the XRD patterns.

\section{$3.4 \mathrm{Bi}_{4} \mathrm{~B}_{2} \mathrm{O}_{9}$}

The compound $\mathrm{Bi}_{4} \mathrm{~B}_{2} \mathrm{O}_{9}$ was synthesized by a microwave method by grinding $(\mathrm{BiO})_{2} \mathrm{CO}_{3}$ and $\mathrm{H}_{3} \mathrm{BO}_{3}$ into a pellet, which was placed in amorphous carbon and irradiated
Table 1. Microwave prepared electrode materials and their preparative conditions.

\begin{tabular}{|c|c|c|c|}
\hline No. & $\begin{array}{c}\text { Electrode } \\
\text { material }\end{array}$ & Reactants & $\begin{array}{l}\text { Time } \\
(\min )\end{array}$ \\
\hline 1 & $\mathrm{LiMn}_{2} \mathrm{O}_{4}$ & $\begin{array}{l}\mathrm{Li}_{2} \mathrm{CO}_{3}+\mathrm{MnO}_{2} * \\
\mathrm{LiI}+\mathrm{MnO}_{2}\end{array}$ & $\begin{array}{l}5 \\
6\end{array}$ \\
\hline 2 & $\mathrm{CuBi}_{2} \mathrm{O}_{4}$ & $\begin{array}{l}\mathrm{CuO}+\mathrm{Bi}_{2} \mathrm{O}_{3} \\
\mathrm{CuO}+(\mathrm{BiO})_{2} \mathrm{CO}_{3} *\end{array}$ & $\begin{array}{l}5 \\
1\end{array}$ \\
\hline 3 & $\mathrm{LiCoO}_{2}$ & $\begin{array}{l}\mathrm{LiOH}+\mathrm{Co}\left(\mathrm{NO}_{3}\right)_{2} \cdot 6 \mathrm{H}_{2} \mathrm{O}^{\#} \\
\mathrm{Li}_{2} \mathrm{CO}_{3}+\mathrm{Co}\left(\mathrm{NO}_{3}\right)_{2} \cdot 6 \mathrm{H}_{2} \mathrm{O}^{*}\end{array}$ & $\begin{array}{r}10 \\
5\end{array}$ \\
\hline 4 & $\mathrm{Bi}_{4} \mathrm{~B}_{2} \mathrm{O}_{9}$ & $(\mathrm{BiO})_{2} \mathrm{CO}_{3}+\mathrm{H}_{3} \mathrm{BO}_{3}$ & $\begin{array}{l}1 \text { (20\% power })+ \\
3(100 \% \text { power })\end{array}$ \\
\hline
\end{tabular}

*indicates that reactants were pelletized and placed in amorphous carbon (secondary heater);

\#indicates solution route using microwaves.

with microwaves. The initial heating was done at low power $(20 \%)$ for about a minute for the removal of water and subsequently it was kept at high power for $3 \mathrm{~min}$. The product was confirmed to be monophasic $\mathrm{Bi}_{4} \mathrm{~B}_{2} \mathrm{O}_{9}$ using X-ray diffraction (figure 5). In comparison, the conventional method (Levin and McDaniel 1962) is tedious and involves several intermittent grindings.

The various electrode materials prepared by the microwave route and their preparative conditions are summarized in table 1.

\section{Conclusions}

Electrode materials, which find potential applications in Li batteries, have been synthesized by a microwave route for the first time. The method should prove to be very attractive for large-scale production in view of the very short time involved for their synthesis. 


\section{Acknowledgement}

Thanks are due to European Commission for the financial support through the project INCO-DC 950400.

\section{References}

Ahmad I, Dalton R C and Clark D E 1991 J. Microwave Power \& Electromagnetic Energy 26128

Baghurst D R and Mingos D M P 1988 J. Chem. Soc., Chem. Commun. 829

Baghurst D R, Chippindale A M and Mingos D M P 1988 Nature 332311

Barboux P, Tarascon J M and Shokoohi F K 1991 J. Solid State Chem. 94185

Boivin M J C, Thomas D and Tridot G 1973 Compt. Rend. C276 1105

Clark D E, Ahmad I and Dalton R C 1991 Mater. Sci. Engg. A144 91

Dahn J R, von Sacken U and Michal C A 1990 Solid State Ionics 4487

Dahn J R, von Sacken U, Juzkow M W and Janaby H A 1991 J. Electrochem. Soc. 1382207

Fong R, Von Sacken U and Dahn J R 1990 J. Electrochem. Soc. 1372009

Gummow R J, Thackery M M, David W I F and Hull S 1992 Mater. Res. Bull. 27327

Guyomard D and Tarascon J M 1992 J. Electrochem. Soc. 139 937

Huang H and Bruce P G 1994 J. Electrochem. Soc. 141 L76

Huang H and Bruce P G 1995 J. Power Sources 5452

Jones S D and Akridge J R 1995 in Handbook of solid state batteries and capacitors (ed.) M Z A Munshi (Singapore: World Scientific) p. 209

Kanno R, Takeda Y, Ichikawa T, Nakanashi K and Yamamoto O 1989 J. Power Sources 26535

Kiggans J O, Hubbard C R, Steele R R, Kimrey H D, Holcombe C E and Tiegs T N 1991 Ceram. Trans. 21403

Kladnig W F and Horn J E 1990 Ceram. Int. 1699

Kniep R 1993 Angew. Chem. 321411

Landry C C and Barron A R 1993 Science 2601653

Lazzari M and Scrosati B 1980 J. Electrochem. Soc. 127773
Levin E M and McDaniel C L 1962 J. Am. Ceram. Soc. 45 355

Mingos D M P and Baghurst D R 1991 Chem. Soc. Rev. 201

Mingos D M P and Baghurst D R 1992 Br. Ceram. Trans. J. 91 124

Mizushima K, Jones P C, Wiseman P J and Goodenough J B 1980 Mater. Res. Bull. 15783

Mohri M et al 1989 J. Power Sources 26545

Murphy D W and Carides J N 1979 J. Electrochem. Soc. 126 349

Murphy D W, De Salvo F J, Carides J N and Waszczak J V 1978 Mater. Res. Bull. 131395

Nagaura T 1990 Prog. Batt. Col. Cells 920

Ozawa K 1994 Solid State Ionics 69212

Peled E, Lombardi A and Schlaikjer C R 1983 J. Electrochem. Soc. 1301362

Ramesh P D and Rao K J 1995 Adv. Mater. 7177

Ramesh P D, Vaidhyanathan B, Ganguli M and Rao K J 1994 J. Mater. Res. 93057

Rao K J and Ramesh P D 1995 Bull. Mater. Sci. 18447

Rao K J, Vaidhyanathan B, Ganguli M and Ramakrishnan P A 1999a Chem. Mater. 11882

Rao K J, Ramakrishnan P A and Gadagkar R 1999b J. Solid State Chem. 148100

Tarascon J M and Guyomard D 1991 J. Electrochem. Soc. 138 2864

Tarascon J M and Guyomard D 1993 Electrochim. Acta 38 1221

Thomas M G S R, Bruce P G and Goodenough J B $1985 \mathrm{~J}$. Electrochem. Soc. 1321521

Vaidhyanathan B and Rao K J 1997a Chem. Mater. 91196

Vaidhyanathan B and Rao K J 1997b J. Mater. Res. 123225

Vaidhyanathan B, Ganguli M and Rao K J 1994 J. Solid State Chem. 113448

Vaidhyanathan B, Ganguli M and Rao K J 1995 Mater. Res. Bull. 301173

Vaidhyanathan B, Raizada P and Rao K J 1997 J. Mater. Sci. Lett. 162022

Vaidhyanathan B, Prem Kumar C and Rao K J 1998 J. Phys. Chem. Solids $\mathbf{5 9} 121$

Whittaker A G and Mingos D M P 1992 J. Chem. Soc., Dalton Trans. 2751 